\title{
Pengabaian Penerapan Sanksi oleh Pejabat Berwenang terhadap Pelanggaran Disiplin Berat Pegawai Negeri Sipil
}

\author{
Waiver of Sanctions Implementation by Authorized Officers to Serious \\ Disciplinary Offenses of Civil Servants
}

\author{
Fahrudin Rasyid \\ Universitas Halu Oleo \\ E-mail: Fahrudin_rasyid@yahoo.com \\ La Sensu \\ Pascasarjana Universitas Halu Oleo \\ E-mail: lasensu_march72@yahoo.com \\ Kamaruddin Jafar \\ Pascasarjana Universitas Halu Oleo \\ E-mail: Kamaruddinjafar88@gmail.com
}

\begin{abstract}
This study examines the neglect of the application of sanctions by competent authorities for civil servants who violate the rules of staffing discipline can be considered as violations of law, as well as knowing legal sanctions for authorized officials who ignore the application of sanctions for gross disciplinary violations of Civil Servants.

This study is Normative or doctrinal Legal research in the nature of prescriptive research. The approach used is the Law approach and the historical approach with legal materials used in the form of secondary data consisting of primary, secondary and non-legal legal materials. Legal material collection techniques are carried out by library research and analyzed using deductive logic.

Based on this research, it was obtained the result that the neglect of the application of sanctions by competent authorities against violations of severe discipline of Civil Servants could be qualified for violations of law. Because it has violated legal provisions in Article 21 paragraph (1), (2), (3), and (4) Government Regulation Number 53 of 2010 and does not carry out legal norms in Article 87 paragraph (4) letter $b$ of the 5-year Law 2014 and Article 250 letter b Government Regulation Number 11 of 2017.

Sanctions of officials who ignore the application of sanctions against violations of severe discipline of Civil Servants, these officials are sentenced to disciplinary superiors that are similar to the types of disciplinary penalties that should be imposed on civil servants who commit disciplinary violations and if the imposition of
\end{abstract}


severe disciplinary sanctions on civil servants as the authority of the regional head as a staffing official who does not carry out disciplinary sanctions can be qualified for violations of the law and given legal sanctions, namely dismissal from his office.

Keyword: abandonment; violation of law; civil servants

Abstrak: Penelitian ini mengkaji tentang pengabaian penerapan sanksi oleh pejabat berwenang bagi pegawai negeri sipil yang melanggar peraturan disiplin kepegawaian dapat dinilai sebagai pelanggaran hukum, serta mengetahui sanksi hukum bagi pejabat berwenang yang mengabaikan penerapan sanksi terhadap pelanggaran disiplin berat Pegawai Negeri Sipil.

Penelitian ini adalah penelitian Hukum Normatif atau doktrinal dalam sifat penelitian preskriptif. Pendekatan yang digunakan adalah pendekatan UndangUndang dan pendekatan historis dengan bahan hukum yang digunakan berupa data sekunder yang terdiri dari bahan hukum primer, sekunder dan non hukum. Teknik pengumpulan bahan hukum dilakukan dengan penelitian kepustakaan dan dianalisis menggunakan logika deduktif.

Berdasarkan penelitian ini diperoleh hasil bahwa Pengabaian penerapan sanksi oleh pejabat berwenang terhadap pelanggaran disiplin berat Pegawai Negeri Sipil dapat dikualifikasi perbuatan pelanggaran hukum. Karena telah menyalahi ketentuan hukum pada pasal 21 ayat (1), (2), (3), dan (4) Peraturan Pemerintah Nomor 53 tahun 2010 serta tidak menjalankan norma hukum dalam Pasal 87 ayat (4) hurufb Undang-undang 5 tahun 2014 dan Pasal 250 huruf b Peraturan Pemerintah Nomor 11 tahun 2017.

Sanksi pejabat yang mengabaikan penerapan sanksi terhadap pelanggaran Disiplin berat Pegawai Negeri Sipil, pejabat tersebut dijatuhi hukuman disiplin atasannya yang sama dengan jenis hukuman disiplin yang seharusnya dijatuhkan kepada PNS yang melakukan pelanggaran disiplin dan apabila penjatuhan sanksi disiplin berat PNS menjadi kewenangan kepala daerah selaku pejabat pembina kepegawaian tidak melaksanakan penjatuhan sanksi disiplin dapat dikualifikasi perbuatan pelanggaran hukum serta diberikan sanksi hukum yaitu diberhentikan dari jabatannya.

Kata kunci: Pengabaian; pelanggaran hukum; pegawai negeri sipil

\section{PENDAHULUAN}

Indonesia sebagai negara hukum telah menempatkan landasan yuridis bagi warga negaranya dalam memperoleh pekerjaan yang layak, sebagaimana tertulis dalam Pasal 27 ayat 2 Undang-Undang Dasar 1945, yang berbunyi: "Tiap-tiap warga negara berhak atas pekerjaan dan penghidupan yang layak bagi kemanusiaan". Isi pasal tersebut, Negara menyadari akan arti penting dan mendasarnya masalah pekerjaan bagi kelangsungan hidup manusia.

Pegawai Negeri Sipil sebagai abdi Negara dan abdi masyarakat yang dengan penuh kesetiaan dan ketaatan kepada Pancasila, Undang- Undang Dasar 1945. Tugas kenegaraan dan jabatan yang diemban Pegawai Negeri agar dapat berjalan dengan lancar, dan dapat menunjang kelancaran pembangunan Nasional, maka setiap Pegawai Negeri tersebut harus memiliki kemampuan dan kualitas tinggi serta dengan tingkat disiplin yang 
tinggi pula. Hal tersebut tidak hanya kemampuan dalam bidang keterampilannya saja, akan tetapi harus didukung dengan tingkat kualitas diri secara total, karena kualitas manusia itu ditentukan oleh pengetahuan, keterampilan, dan sikap mental (Knowledge, Skill, and Attitude). ${ }^{1}$ Intinya jelas terlihat bahwa suatu keterampilan yang dimiliki seseorang tidak cukup untuk bisa dikatakan bahwa orang tersebut mempunyai kualitas diri yang baik. F.X. Oerip S. Poerwopoespito mengatakan bahwa pada dasarnya kualitas manusia secara total ditentukan oleh², Kualitas Teknis, Kualitas Fisik, Kualitas Sikap Mental.

Pegawai Negeri Sipil yang melakukan pelanggaran disiplin akan dijatuhi hukuman disiplin. Sebagaimana dimaksud di dalam Undang- Undang Nomor 5 Tahun 2014 Pasal 86 ayat (3). Untuk mewujudkan Pegawai Profesional (bebas dari intervensi politik) dan bermoral (bebas dari Korupsi, Kolusi dan Nepotisme) mutlak diperlukan peraturan disiplin Pegawai Negeri Sipil yang dapat dijadikan pedoman dalam menegakkan disiplin, sehingga dapat menjamin terpeliharanya tata tertib dan kelancaran pelaksanaan tugas serta dapat mendorong Pegawai Negeri Sipil untuk lebih produktif berdasarkan sistem karier dan sistem prestasi kerja.

Peraturan Nomor 53 Tahun 2010 tentang Disiplin Pegawai Negeri Sipil adalah peraturan yang mengatur kewajiban, larangan dan sanksi apabila kewajiban-kewajiban tidak ditaati atau dilanggar oleh Pegawai Negeri Sipil. ${ }^{3}$ dengan maksud untuk mendidik dan membina Pegawai Negeri Sipil, bagi mereka yang melakukan pelanggaran atas kewajiban dan larangan dikenakan sanksi berupa hukuman disiplin. ${ }^{4}$

Solusinya yaitu dengan adanya sanksi/tindakan secara tegas bilamana seorang Pegawai Negeri Sipil terbukti melakukan pelanggaran disiplin yang tujuan untuk memberikan efek jera dan shock terapi agar Pegawai Negeri Sipil yang lain tidak meniru atau melakukan pelanggaran yang lebih berat lagi. Kelancaran pelaksanaan pemerintahan dan pembangunan nasional terutama tergantung dari kesempurnaan aparatur negara dan kesempurnaan aparatur negara pada pokoknya tergantung dari kesempurnaan pegawai negeri. 5

1 F. X. Oerip S. Poerwopoespito dan T.A. Tatag Utomo, Mengatasi Krisis Manusia di Perusahaan, Solusi Melalui Pengembangan Sikap Mental, Jakarta: Grasindo, 2000, hlm. 26.

2 Ibid., hlm. 27.

3 Moh. Mahfud MD, Hukum Kepegawaian Indonesia, Yogyakarta, Liberty, 1988, hlm. 121.

4 M. Suparno, Rekayasa Pembangunan Watak dan Moral Bangsa, Jakarta: PT. Purel Mundial, 1992, hlm. 85.

5 Nainggolan, Pembinaan Pegawai Negeri Sipil, Jakarta: Pertja, 1987, hlm. 23. 
Permasalahan kemudian terdapat Pegawai Negeri Sipil pada pemerintah kota Kendari berdasarkan Putusan Mahkamah Agung Republik Indonesia Nomor: 57 K/Pid.Sus/2013 An. NBL yang menolak permohonan kasasi dari Pemohon Kasasi dan menguatkan Putusan Pengadilan Tinggi dan Putusan Pengadilan Negeri yang menyatakan NBL secara sah dan meyakinkan melakukan tindak pidana korupsi. Maka berdasarkan Pasal 13 angka 8 Peraturan Pemerintah Nomor 53 tahun 2010 tentang Disiplin Pegawai Negeri Sipil, Pasal 87 ayat (4) huruf b Undang-undang 5 tahun 2014 Aparatur Sipil Negara dan Pasal 250 huruf b Peraturan Pemerintah Nomor 11 tahun 2017 tentang Manajemen PNS. PNS yang dihukum penjara atau kurungan berdasarkan putusan pengadilan yang telah memiliki kekuatan hukum tetap karena melakukan tindak pidana kejahatan jabatan atau tindak pidana kejahatan yang ada hubungannya dengan jabatan/korupsi.

Berdasarkan Peraturan Perundang-undangan di atas perbuatan korupsi adalah merupakan pelanggaran disiplin berat Pegawai Negeri Sipil yang sanksinya adalah Pemberhentian Tidak Dengan Hormat (PTDH) yang pemberhentiannya ditetapkan oleh Pejabat Pembina Kepegawaian (kepala daerah) namun kenyataannya pejabat pembina kepegawaian yang seharusnya berkewajiban dan berwenang menjatuhkan sanksi terhadap pelanggaran disiplin yang dilakukan Pegawai Negeri Sipil justru melakukan pengabaian (Pengabaian dalam kamus besar bahasa Indonesia adalah suatu tindakan atau perbuatan yang melalaikan kewajiban, tugas dan pekerjaan). Dengan demikian berdasarkan rumusan norma peraturan perundang-undangan dijelaskan bahwa Pejabat yang berwenang menghukum wajib menjatuhkan hukuman disiplin kepada PNS yang melakukan pelanggaran disiplin sebagaimana diatur dalam Pasal 21 ayat (1) Peraturan Pemerintah Nomor 53 Tahun 2010 dan Undang-Undang Nomor 23 tahun 2014 tentang Pemerintahan Daerah, dalam Pasal 67 huruf b kewajiban kepala daerah yaitu: "menaati seluruh ketentuan peraturan perundang-undangan"

Berdasarkan latar belakang di atas penulis akan menganalisis terhadap Pengabaian Penerapan Sanksi Oleh Pejabat Berwenang Terhadap Pelanggaran Disiplin Berat Pegawai Negeri Sipil. Rumusan masalah dalam pembahasan ini yaitu: 1) apakah pengabaian penerapan sanksi Disiplin oleh pejabat berwenang terhadap pelanggaran disiplin berat Pegawai Negeri Sipil merupakan pelanggaran hukum? Dan 2) apakah sanksi Hukum dapat dikenakan terhadap Pejabat yang mengabaikan penerapan sanksi atas pelanggaran disiplin berat Pegawai Negeri Sipil? 


\section{METODE PENELITIAN}

Metode Penelitian ini adalah penelitian hukum normatif (normative legal research), yaitu penelitian yang dilakukan dengan cara mengkaji peraturan perundang-undangan yang berlaku atau diterapkan terhadap suatu permasalahan hukum tertentu. Penelitian normatif sering kali disebut dengan penelitian doktrinal, yaitu penelitian yang objek kajiannya adalah dokumen peraturan perundang-undangan dan bahan pustaka.

Sehubungan dengan tipe penelitian yang digunakan yaitu penelitian normatif, maka terdapat beberapa pendekatan penelitian hukum antara lain pendekatan UndangUndang/Peraturan Perundang-undangan (statue approach), pendekatan kasus (case approach), pendekatan historis (historical approach), pendekatan perbandingan (comparative approach), dan pendekatan konseptual (conseptual approach). ${ }^{6}$

Prosedur pengumpulan bahan hukum dilakukan dengan cara mengumpulkan bahan-bahan kepustakaan sebagai bahan hukum primer dan sekunder. Bahan-bahan hukum primer terdiri dari perundang-undangan, catatan-catatan resmi, atau risalah dalam pembuatan peraturan perundang-undangan dan putusan-putusan hakim. ${ }^{7}$ Sedangkan bahan-bahan Hukum Sekunder yaitu bahan hukum yang erat hubungannya dengan bahan hukum primer dan dapat membantu menganalisis dan memahami bahan hukum primer. ${ }^{8}$ Bahan hukum sekunder berupa publikasi tentang hukum yang bukan merupakan dokumen-dokumen resmi. ${ }^{9}$ Dan bahan hukum tersier Bahan hukum tersier yang digunakan dalam penelitian ini adalah Kamus Besar Bahasa Indonesia maupun situs internet/ensiklopedia yang relevan dengan sanksi disiplin.

\section{ANALISIS DAN PEMBAHASAN}

\section{Pengaturan Disiplin Pegawai Negeri Sipil Dalam Peraturan Perundang-undangan di}

\section{Indonesia}

Berdasarkan Undang-Undang Nomor 5 tahun 2014 tentang Aparatur Sipil Negara dalam pasal 1 angka 1 Aparatur Sipil Negara yang selanjutnya disingkat ASN adalah profesi bagi pegawai negeri sipil dan pegawai pemerintah dengan perjanjian kerja yang bekerja pada instansi pemerintah. Dan Pasal 1 angka 3 Pegawai Negeri Sipil yang selanjutnya disingkat

\footnotetext{
Peter Mahmud Marzuki, Penelitian Hukum, Jakarta: Kencana Prenada Media Group, 2005, hlm. 93. Soetandyo Wignjosoebroto, Hukum Konsep dan Metode, Malang: Setara Press, 2013, hlm. 67.

8 Soerjono Soekanto, Sri Mamudji, Penelitian Hukum Normatif Suatu Tinjauan Singkat Cetakan ke-11. Jakarta: PT. Raja Grafindo Persada, 2009. hlm. 13.

9 Ronny Hanitijo, Metode Penelitian Hukum, Jakarta: Ghalia Indonesia, 1993, hlm. 43.
} 
PNS adalah warga Negara Indonesia yang memenuhi syarat tertentu, diangkat sebagai Pegawai Aparatur Sipil Negara secara tetap oleh pejabat pembina kepegawaian untuk menduduki jabatan pemerintahan.

Perbuatan Pegawai Negeri Sipil yang melanggar hal-hal yang dilarang seperti yang ditentukan dalam Undang-undang Nomor 5 Tahun 2014 tentang Aparatur Sipil Negara dan atau Peraturan Pemerintah Nomor 53 Tahun 2010 tentang Peraturan Disiplin Pegawai Negeri Sipil merupakan pelanggaran disiplin. Pasal 5 Peraturan Pemerintah Nomor 53 Tahun 2010 diatur bahwa PNS yang tidak menaati ketentuan sebagaimana dimaksud Pasal 3 dan/atau Pasal 4 dijatuhi hukuman disiplin. Apabila Pegawai Negeri Sipil (PNS) tidak menaati kewajiban dan larangan yang telah ditentukan dalam peraturan pemerintah tersebut, maka akan dikenakan sanksi atau hukuman yang juga telah diatur dalam Peraturan Pemerintah Nomor 53 Tahun 2010 tentang Peraturan Disiplin Pegawai Negeri Sipil.

Adapun Larangan Pegawai Negeri Sipil diatur di dalam Pemerintah Nomor 53 Tahun 2010 Pasal 4 antara lain yaitu Menerima hadiah atau suatu pemberian apa saja dari siapa pun juga yang berhubungan dengan jabatan dan/ atau pekerjaannya atau biasa disebut sebagai perbuatan korupsi yang merupakan pelanggaran disiplin berat pegawai negeri sipil.

Hukuman disiplin adalah hukuman yang dijatuhkan kepada Pegawai Negeri Sipil karena melanggar peraturan disiplin Pegawai Negeri Sipil. Hukum disiplin diberikan tujuan untuk memperbaiki dan mendidik Pegawai Negeri Sipil yang melakukan pelanggaran disiplin. Dalam menentukan jenis hukuman disiplin yang akan dijatuhkan haruslah dipertimbangkan dengan seksama bahwa hukuman disiplin yang akan dijatuhkan itu setimpal dengan pelanggaran disiplin yang dilakukan, sehingga hukuman disiplin tersebut dapat diterima oleh keadilan.

Peraturan Pemerintah Nomor 53 Tahun 2010 pada pasal 5 menjelaskan bahwa, Apabila seorang PNS tidak menaati ketentuan pada Pasal 3 dan 4 maka dijatuhi hukuman disiplin. Adapun hukuman bagi PNS yang melakukan tindak pidana khusus seperti korupsi maka sesuai Undang-undang dan peraturan perundang-undangan diberikan sanksi disiplin berat atau Diberhentikan tidak dengan hormat dari PNS

Dengan demikian penjatuhan sanksi yang tegas wajib dilakukan oleh pejabat yang berwenang sesuai dengan norma yang diatur dalam peraturan perundang-undangan. . 
Dalam konstitusi kita Pasal 1 ayat (3) Undang-Undang Dasar Negara Kesatuan Republik Indonesia Tahun 1945 menyebutkan, bahwa "Negara Indonesia negara hukum". Negara hukum dimaksud adalah negara yang menegakkan supremasi hukum untuk menegakkan kebenaran dan keadilan dan tidak ada kekuasaan yang tidak dipertanggungjawabkan. ${ }^{10}$

\section{Pengabaian Penerapan sanksi ditinjau dari Aspek Hukum}

Prinsip negara hukum bahwa setiap tindakan haruslah dilandasi dengan hukum atau dengan kata lain peraturan perundangan-undangan sehingga dalam melaksanakan tugas dan fungsinya Pejabat yang berwenang menghukum PNS yang melanggar disiplin dalam lingkungan pemerintahannya wajib berpedoman Peraturan Pemerintah Nomor 53 Tahun 2010 sehingga tindakan pemberian sanksi oleh pejabat yang berwenang terhadap pelanggaran disiplin pegawai negeri sipil merupakan tindakan yang legal secara hukum karena didasarkan oleh perintah peraturan perundang-undangan.

Berdasarkan kewenangan tersebut pejabat yang berwenang memberikan sanksi tidak dapat mengabaikan karena memiliki kewenangan secara defacto dan dejure. Setiap tindakan harus bertumpu atas kewenangan yang sah. Kewenangan itu diperoleh melalui tiga sumber, yaitu: atribusi, delegasi dan mandat. Kewenangan delegasi dan mandat adalah kewenangan yang berasal dari pelimpahan. Maka telah jelas menurut pendapat Philipus M Hadjon bahwa pejabat yang berwenang memberi sanksi telah ada pendelegasian kewenangan serta mandat dalam peraturan perundang-undangan.

Untuk menguatkan argumentasi bahwa PNS dalam melaksanakan tugasnya wajib selalu merujuk pada peraturan perundang-undangan telah pula dijelaskan dalam pasal 3 angka 4 dimana secara tegas dirumuskan dalam PP Nomor 53 Tahun 2010 tentang Disiplin Pegawai Negeri Sipil bahwa Pegawai Negeri Sipil wajib menaati segala ketentuan peraturan perundang-undangan.

Dalam rumusan norma peraturan perundang-undangan dijelaskan bahwa Pejabat yang berwenang menghukum wajib menjatuhkan hukuman disiplin kepada PNS yang melakukan pelanggaran disiplin sebagaimana diatur dalam Pasal 21 ayat (1) Peraturan Pemerintah Nomor 53 Tahun 2010. Selanjutnya apabila dalam pelaksanaan pemberian sanksi disiplin berat merupakan kewenangan kepala daerah maka kepala daerah wajib

10 Majelis Permusyawaratan Rakyat Republik Ind onesia,Panduan Pemasyarakatan Undang-Undang Dasar Republik Indonesia Tahun 1945, Jakarta: Sekertaris Jenderal MPR RI, 2010, hlm. 46. 
melaksanakan keputusan tersebut untuk melaksanakan amanah peraturan perundangundangan.

Berdasarkan Undang-Undang Nomor 23 Tahun 2014 tentang Pemerintahan Daerah, kewajiban kepala daerah dan wakil kepala daerah meliputi: menaati seluruh ketentuan peraturan perundang-undangan. Dari uraian di atas peneliti berpendapat bahwa kewenangan pejabat tertuang dalam peraturan, sebagaimana dalam teori atribusi sebagai teori wewenang dimana tindakan pejabat berdasarkan wewenang yang ada pada peraturan perundang-undangan. Sehingga secara atribusi jika tindakan pejabat tidak sesuai dengan wewenang yang diberikan oleh peraturan perundang-undangan maka pejabat tersebut dapat dinilai tidak melaksanakan wewenang, jika kewenangan dalam ketentuan perundang-undangan tidak dijalankan maka pejabat tersebut menyalahgunakan wewenang, sehingga dapat dinyatakan sebagai perbuatan pelanggaran hukum sebagaimana tertuang pada pasal 21 yaitu:

1) Pejabat yang berwenang menghukum wajib menjatuhkan hukuman disiplin kepada PNS yang melakukan pelanggaran disiplin.

2) Apabila Pejabat yang berwenang menghukum sebagaimana dimaksud pada ayat (1) tidak menjatuhkan hukuman disiplin kepada PNS yang melakukan pelanggaran disiplin, pejabat tersebut dijatuhi hukuman disiplin atasannya.

3) Hukuman disiplin sebagaimana dimaksud pada ayat (2) sama dengan jenis hukuman disiplin yang seharusnya dijatuhkan kepada PNS yang melakukan pelanggaran disiplin.

4) Atasan sebagaimana dimaksud pada ayat (2), juga menjatuhkan hukuman disiplin terhadap PNS yang melakukan pelanggaran disiplin.

Pengabaian dalam kamus besar bahasa Indonesia adalah suatu tindakan atau perbuatan yang melalaikan kewajiban, tugas dan pekerjaan. Berangkat dari definisi tersebut peneliti berpendapat bahwa pengabaian penerapan sanksi dapat dikatakan sebagai perbuatan melawan hukum dan pelanggaran hukum karena tidak menaati norma tertulis yang termuat dalam Undang-undang dan peraturan perundang-undangan yang mana telah diatur dalam undang-undang nomor 30 tahun 2014 pasal 53 Ayat (6) bahwa Badan dan/atau Pejabat Pemerintahan wajib menetapkan Keputusan untuk melaksanakan putusan Pengadilan sebagaimana dimaksud pada ayat (5) paling lama 5 (lima) hari kerja sejak putusan Pengadilan ditetapkan, undang-undang nomor 23 tahun 2014 pasal 67 huruf b bahwa kepala daerah wajib menaati seluruh ketentuan peraturan perundang- 
undangan serta menjalankan norma hukum yang telah diatur dalam hukum positif dan telah pula diatur dalam peraturan pemerintah Nomor 53 tahun 2010 pasal 21 Ayat (1), (2), (3), dan (4) serta diatur dalam teori wewenang atribusi. Berdasarkan wewenang atribusi tersebut pejabat yang berwenang memberikan sanksi tidak dapat mengabaikan karena memiliki kewenangan secara dejure.

\section{Sanksi Hukum Pejabat Administrasi Negara yang mengabaikan penerapan Sanksi Disiplin}

Seseorang yang memangku jabatan berhak menggunakan jabatan itu di dalam tugas, kedudukan dan kewenangannya. Atas penggunaan jabatan itu pada gilirannya ia berkewajiban bertanggung jawab atas tindakan-tindakan dalam jabatannya. Jabatan itu melekat pada diri seseorang, maka orang yang memangku jabatan disebut pejabat. Dan kontinuitas jabatan dapatlah dilihat pada bergantinya pejabat terhadap sesuatu jabatan. Jabatan bersifat tetap sedangkan pejabat dapat berganti orang yang mendudukinya.

Jabatan sebagai subyek hukum dalam lapangan HAN adalah sebagai pendukung hak dan kewajiban, oleh karena itu jabatan juga memiliki kewenangan hukum sebagaimana pegawai negeri. Karena kewenangannya itu ia berhak melakukan sesuatu yang dibarengi dengan pelaksanaan kewajiban.

Wewenang mengandung arti hak dan kewajiban. Hak berisi kebebasan untuk melakukan atau tidak melakukan tindakan tertentu atau menuntut pihak lain untuk melakukan tindakan tertentu. Kewajiban memuat keharusan untuk melakukan atau tidak melakukan tindakan tertentu. ${ }^{11}$ Dalam hukum administrasi negara wewenang pemerintahan yang bersumber dari peraturan perundang-undangan diperoleh melalui cara-cara yaitu atribusi, delegasi dan mandat.

Prinsip negara hukum bahwa setiap tindakan haruslah dilandasi dengan hukum atau dengan kata lain peraturan perundangan-undangan sehingga dalam melaksanakan tugas dan fungsinya Pejabat yang berwenang menghukum wajib berpedoman pada peraturan perundang-undangan sehingga tindakan pemberian sanksi oleh pejabat yang mengabaikan penerapan sanksi bagi pelanggar disiplin berat pegawai negeri sipil merupakan tindakan yang legal secara hukum karena didasarkan oleh perintah peraturan perundang-undangan.

11 Ridwan HR, Hukum Administrasi Negara, Jakarta: Raja Grafindo Persada, 2006. 
Dalam rumusan norma peraturan perundang-undangan dijelaskan bahwa Pejabat yang berwenang menghukum wajib menjatuhkan hukuman disiplin kepada PNS yang melakukan pelanggaran disiplin apabila dianggap telah melakukan pelanggaran disiplin PNS dan tentu saja wajib mendapatkan hukuman disiplin. Tujuan hukuman disiplin adalah untuk memperbaiki dan mendidik Pegawai Negeri Sipil yang melakukan pelanggaran disiplin. Karena itu setiap pejabat yang berwenang menghukum sebelum menjatuhkan hukuman disiplin harus memeriksa lebih dahulu Pegawai Negeri Sipil yang melakukan pelanggaran disiplin.

Bahwa dalam peraturan pemerintah nomor 53 tahun 2010 telah secara jelas dirumuskan dalam Pasal 21 bahwa:

1) Pejabat yang berwenang menghukum wajib menjatuhkan hukuman disiplin kepada PNS yang melakukan pelanggaran disiplin.

2) Apabila Pejabat yang berwenang menghukum sebagaimana dimaksud pada ayat (1) tidak menjatuhkan hukuman disiplin kepada PNS yang melakukan pelanggaran disiplin, pejabat tersebut dijatuhi hukuman disiplin atasannya.

3) Hukuman disiplin sebagaimana dimaksud pada ayat (2) sama dengan jenis hukuman disiplin yang seharusnya dijatuhkan kepada PNS yang melakukan pelanggaran disiplin.

4) Atasan sebagaimana dimaksud pada ayat (2), juga menjatuhkan hukuman disiplin terhadap PNS yang melakukan pelanggaran disiplin.

Berdasarkan uraian di atas berdasarkan peraturan perundang-undangan pejabat yang berwenang menghukum wajib memberikan sanksi kepada pegawai negeri sipil yang melanggar disiplin hal ini wajib dilakukan untuk menumbuhkan integritas dan disiplin dalam diri Pegawai Negeri sipil sehingga tercipta budaya kerja yang siap melayani bukan dilayani. Hal ini untuk menunjukkan bahwa aparatur sipil negara merupakan pelayan masyarakat yang wajib menunjukkan jati dirinya bahwa dalam bertindak harus menjunjung asas-asas umum pemerintahan (AAUP) yang baik khususnya asas kemanfaatan, kecermatan dan pelayanan yang baik. Berdasarkan Undang-Undang Nomor 30 Tahun 2014 tentang administrasi Pemerintahan.

Bahwa pada prinsipnya, sesuai dengan teori kewenangan Atribusi, menegaskan bahwa pertama, wewenang pejabat ada pada peraturan perundang-undangan, kedua bahwa tindakan pejabat harus sesuai wewenang dalam peraturan perundang-undangan, ketiga bahwa kalau tindakan pejabat tidak sesuai dengan wewenang yang terdapat dalam 
perundang-undangan maka dapat dikualifikasi sebagai pelanggaran hukum, alasannya bahwa tindakan tersebut merupakan penyalahgunaan wewenang, oleh karena telah menyimpang dari wewenang yang ditegaskan dalam ketentuan hukum yang mengaturnya.

Problemnya bahwa kewajiban penerapan sanksi tersebut tidak sejalan dengan pelaksanaan atau pelaksanaannya tidak sesuai Law in the book and law in action dimana terdapat Pegawai Negeri Sipil pada pemerintah kota Kendari berdasarkan Putusan Mahkamah Agung Republik Indonesia Nomor: 57K/Pid.Sus/2013 An. NBL yang telah berkekuatan hukum tetap berdasarkan perundang-undangan pejabat yang berwenang memberhentikan tidak dengan hormat bagi PNS yang telah diputus pengadilan melakukan perbuatan tindak pidana korupsi. Apabila pejabat yang berwenang tidak melaksanakan maka sesuai perundang-undangan dikenakan sanksi administrasi.

Pengenaan Sanksi administrasi berupa Pemberhentian sementara oleh atasan pejabat yang membuat keputusan berdasarkan Pasal 81 ayat (1), ayat (2) huruf b dan huruf c Undang-undang nomor 30 tahun 2014 tentang Administrasi Pemerintahan kepada pejabat pemerintahan karena tidak melaksanakan putusan Pengadilan yang telah ditetapkan sesuai dengan Pasal 53 ayat (6) Undang-undang nomor 30 tahun 2014.

Apabila wewenang penjatuhan sanksi disiplin menjadi kewenangan kepala daerah selaku pembina kepegawaian. Maka wajib dilaksanakan berdasarkan peraturan perundang-undangan karena salah satu kewajiban kepala daerah yaitu menaati seluruh ketentuan peraturan perundang-undangan. Apabila kepala daerah tidak melaksanakan penjatuhan sanksi dapat dikualifikasi pelanggaran hukum dan dapat diberhentikan dari jabatannya karena tidak melaksanakan kewajiban kepala daerah yang dinormakan dalam Undang -Undang.

Kepala daerah dan/atau wakil kepala daerah diberhentikan karena:
a. meninggal dunia;
b. permintaan sendiri; atau
c. diberhentikan.

Diberhentikan sebagaimana dimaksud pada huruf c karena tidak melaksanakan kewajiban kepala daerah dan wakil kepala daerah sebagaimana dimaksud dalam Pasal 67 huruf b yaitu: “menaati seluruh ketentuan peraturan perundang-undangan”. yang pemberhentiannya diusulkan kepada presiden untuk gubernur dan/atau wakil gubernur serta kepada menteri untuk bupati dan/atau wakil bupati atau Walikota dan/atau wakil Walikota berdasarkan putusan mahkamah agung atas pendapat DPRD bahwa kepala 
daerah dan/atau wakil kepala daerah tidak melaksanakan kewajiban kepala daerah dan/atau wakil kepala daerah.

Berdasarkan teori dan norma dalam Undang-undang dan Peraturan perundangundangan penulis berpendapat sanksi hukum apabila Pejabat yang berwenang menghukum, tidak menjatuhkan hukuman disiplin kepada PNS yang melakukan pelanggaran disiplin, pejabat tersebut dijatuhi hukuman disiplin atasannya yang sama dengan jenis hukuman disiplin yang seharusnya dijatuhkan kepada PNS yang melakukan pelanggaran disiplin dan apabila wewenang penjatuhan sanksi disiplin menjadi kewenangan kepala daerah selaku pembina kepegawaian tidak melaksanakan penjatuhan sanksi dapat dikualifikasi perbuatan melawan hukum atau pelanggaran hukum dan dapat diberhentikan dari jabatannya.

\section{KESIMPULAN}

Berdasarkan uraian-uraian yang telah dijelaskan maka penulis dapat menyimpulkan bahwa Pengabaian penerapan sanksi oleh pejabat berwenang terhadap pelanggaran disiplin berat pegawai negeri sipil dapat dinyatakan sebagai perbuatan pelanggaran hukum. Karena tidak menaati norma hukum yang diwajibkan dalam undang-undang dan peraturan perundang-undangan yang mana telah menyalahi ketentuan hukum dalam pasal 21 ayat (1), (2), (3), dan (4) Peraturan Pemerintah 53 tahun 2010, Pasal 87 ayat (4) huruf b Undang-undang 5 tahun 2014, Pasal 53 ayat (6) Undang-undang 30 tahun 2014, Pasal 67 huruf b Undang-undang 23 tahun 2014 dan Pasal 250 huruf b Peraturan Pemerintah Nomor 11 tahun 2017.

Adapun pejabat berwenang yang mengabaikan penerapan sanksi terhadap pelanggaran disiplin berat PNS dikualifikasi sebagai pelanggaran hukum karena tidak melaksanakan kewajiban norma hukum yang diperintahkan dalam Undang-undang dan Peraturan perundang-undangan sehingga berdasarkan Pasal 21 ayat (4) PP 53 tahun 2010 apabila Pejabat yang berwenang menghukum tidak menjatuhkan hukuman disiplin kepada PNS yang melakukan pelanggaran disiplin, pejabat tersebut dijatuhi hukuman disiplin atasannya yang sama dengan jenis hukuman disiplin yang seharusnya dijatuhkan kepada PNS yang melakukan pelanggaran disiplin dan apabila penjatuhan sanksi disiplin berat PNS menjadi kewenangan kepala daerah selaku pejabat pembina kepegawaian mengabaikan penjatuhan sanksi disiplin maka dapat dikualifikasi sebagai pelanggaran 
hukum serta dapat diberhentikan sementara dan/atau tetap dari jabatannya oleh pejabat di atasnya.

Saran yang bisa diberikan dalam karya ilmiah ini adalah sebagai berikut:

1. bahwa usaha dalam mencapai tujuan nasional diperlukan adanya pegawai negeri yang penuh kesetiaan dan ketaatan pada Pancasila dan Undang- Undang Dasar 1945, bermental baik, berwibawa, berdaya guna dan berhasil guna, berkualitas tinggi, mempunyai kesadaran tinggi akan tanggung jawabnya sebagai aparatur negara, abdi negara, serta abdi masyarakat untuk itu agar Pegawai Negeri sipil tetap pada marwahnya sebagai Abdi negara maka pemberian sanksi disiplin oleh pejabat yang berwenang diharapkan tegas sesuai dengan ketentuan yang normakan dalam peraturan Perundang-undangan.

2. pejabat dalam menjalankan tugas dan kewajibannya wajib berpedoman pada ketentuan Peraturan Perundangan-undangan untuk itu Pejabat yang berwewenang ketika tidak memberi sanksi atau memberi sanksi tetapi tidak sesuai dengan jenis sanksi maka pejabat tersebut seharusnya diberikan sanksi berat agar tidak menyalahi kewenangannya.

\section{Daftar Pustaka}

\section{Buku}

Hanitijo, Ronny, Metode Penelitian Hukum, Jakarta: Ghalia Indonesia, 1993.

HR, Ridwan, Hukum Administrasi Negara, Jakarta: Raja Grafindo Persada, 2006.

Majelis Permusyawaratan Rakyat Republik Indonesia,Panduan Pemasyarakatan Undang-

Undang Dasar Republik Indonesia Tahun 1945, Jakarta: Sekertaris Jenderal MPR RI, 2010.

Marzuki, Peter Mahmud, Penelitian Hukum, Jakarta: Kencana Prenada Media Group, 2005. MD, Moh. Mahfud, Hukum Kepegawaian Indonesia, Yogyakarta, Liberty, 1988.

Nainggolan, Pembinaan Pegawai Negeri Sipil, Jakarta: Pertja, 1987.

Poerwopoespito, F. X. Oerip S. dan T.A. Tatag Utomo, Mengatasi Krisis Manusia di Perusahaan, Solusi Melalui Pengembangan Sikap Mental, Jakarta: Grasindo, 2000.

Soekanto, Soerjono, Sri Mamudji, Penelitian Hukum Normatif Suatu Tinjauan Singkat Cetakan ke-11. Jakarta: PT. Raja Grafindo Persada, 2009.

Suparno, M., Rekayasa Pembangunan Watak dan Moral Bangsa, Jakarta: PT. Purel Mundial, 1992. 
Wignjosoebroto, Soetandyo, Hukum Konsep dan Metode, Malang: Setara Press, 2013.

\section{Peraturan Perundang-Undangan}

Undang-undang Nomor 5 Tahun 2014 tentang Aparatur Sipil Negara (Lembaran Negara Republik Indonesia Tahun 2014 Nomor 6, Tambahan Lembaran Negara Republik Indonesia Nomor 5494).

Undang-Undang Nomor 23 Tahun 2014 tentang Pemerintahan Daerah (Lembaran Negara Republik Indonesia Tahun 2014 Nomor 244, Tambahan Lembaran Negara Republik Indonesia Nomor 5587) sebagaimana telah diubah beberapa kali terakhir dengan Undang-Undang Nomor 9 Tahun 2015 tentang Perubahan Kedua Atas UndangUndang Nomor 23 Tahun 2014 tentang Pemerintahan Daerah (Lembaran Negara Republik Indonesia Tahun 2015 Nomor 58, Tambahan Lembaran Negara Republik Indonesia Nomor 5679).

Undang-undang Nomor 30 Tahun 2014 tentang Administrasi Pemerintahan (Lembaran

Negara Republik Indonesia Tahun 2014 Nomor 292, Tambahan Lembaran Negara Republik Indonesia Nomor 5601).

Peraturan Pemerintah Nomor 53 Tahun 2010 tentang Disiplin Pegawai Negeri Sipil

(Lembaran Negara Republik Indonesia Tahun 2010 Nomor 74, Tambahan Lembaran Negara Republik Indonesia Nomor 5135).

Peraturan Pemerintah Nomor 11 tahun 2017 tentang Menajemen Pegawai Negeri Sipil (Lembaran Negara Republik Indonesia Tahun 2017 Nomor 73, Tambahan Lembaran Negara Republik Indonesia Nomor 6037); 